\title{
針対平板電極系コロナ放電場を利用したオゾン送風機構*
}

\author{
川本広 行*1, 増 成 幸 数*2, 梅津 信二郎*3
}

\section{An Ozone Fan Utilizing Pin-to-Plate Corona Discharge Field}

\author{
Hiroyuki KAWAMOTO*4, Yukikazu MASUNARI and Shinjiro UMEZU \\ ${ }^{* 4}$ Department of Mechanical Engineering, Waseda University, \\ 3-4-1 Okubo, Shinjuku-ku, Tokyo, 169-8555 Japan
}

\begin{abstract}
Experimental and theoretical research has been conducted to investigate basic characteristics of an ozone fan utilizing the ionic wind induced in the pin-to-plate corona discharge field. When a high voltage was applied between the electrodes, the ionic wind, which included ozone, flowed from the pin elecrode to a hole of the plate electrode. It was deduced that ( 1 ) the ozone concentration is almost linear with respect to the corona current, (2) the ozone concentration was high with the large pin diameter but almost irrelevant with the gap between the electrodes, ( 3 ) the energy efficiency of the negative corona was about 14 times higher that of the positive corona, but it was only several \%, (4) the ozone generation was reduced at high temperature. It was estimated that the several ppm ozone could be generated and flowed utilizing the negative discharge and the ozone generation was almost eliminated by turning off the polarity.
\end{abstract}

Key Words: Electrohydrodynamics, Ozone, Fan, Corona Discharge, Ionic Wind

\section{1. 緒言}

オゾンはフッ素につぐ強力な酸化力があり, 分解し て酸素になるため 2 次污染がなく,生成物も毒性が低 いなどの優れた性質を持つ化学物質である.このため オゾンは, その脱臭力, 脱色力, 殺菌力による下水処 理, 上水道における高度水処理, プールや水族館にお ける浄水処理, 食品工業における殺菌・脱臭, 空気の 浄化など広範囲の分野で利用されている(1).さらに近 年では，このような大規模な利用だけでなく，局所的 な殺菌や表面改質など微小な部分への選択的な利用 も注目されている(2)-(4).このような目的には，これま での大規模なオゾナイザーよりも, 小型で簡便なオゾ ン発生機構が適していると考えられる.

いっぽう我々はこれまで, 針対平板電極系コロナ放

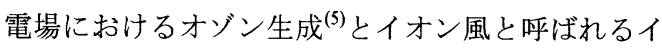
オンの泳動に励起される空気流を利用したマイクロ 送風機構 ${ }^{(6)} の$ 研究を行ってきた. 針対平板電極系コロ ナ放電場では, オゾン生成と送風という2つの独立な

\footnotetext{
* 原稿受付 2007 年 3 月 13 日.

*1 正員, フェロー, 早稲田大学理工学術院 (荿 169-8555 東京都 新宿区大久保 3-4-1)

*2 早稲田大学理工学研究科.

*3 正員, 早稲田大学理工学術院.

E-mail : kawa@waseda.jp
}

現象が同時に発生するので,これらを組み合わせれば, 局所的な殺菌や表面改質に利用できる簡便な機構が 実現できるのではないかと考えて研究を行った.その 結果, 機械的なファンなどを用いることなく非常に簡 単な装置でオゾンを供給できることや, 極性の切り替 えによってオゾンを発生させたり抑止したりするこ とができることなどを明らかにしたので報告する．

\section{2. 実験装置}

2.1 オゾン送風機構 図 1 に示すような, 針対 平板電極系での放電を利用したオゾン送風機構を考 案した. すなわち, 針電極と中央に穴を有する平板電 極間に高電圧を印加すると, 針電極先端でコロナ放電 が生じ, 平板電極の穴からイオン風が排出される. イ オン風とは, 放電場で電離して生じたイオンが電界に よって泳動するとき, 周囲の中性分子に衝突すること によって生じる空気流のことである.コロナ放電場で は同時にオゾンが生成するので, オゾンが含まれるイ オン風が送風されることになる. 本研究では, 空隙長 $G$ と針電極半径 $r_{0}$ をパラメータに, コロナ電流 $I$ と才 ゾン濃度の関係や, エネルギー効率, 温度特性, およ びオゾン送風機構としての性能を評価した. なお, 平 板電極中央の穴径は $5 \mathrm{~mm}$ で一定とした。 


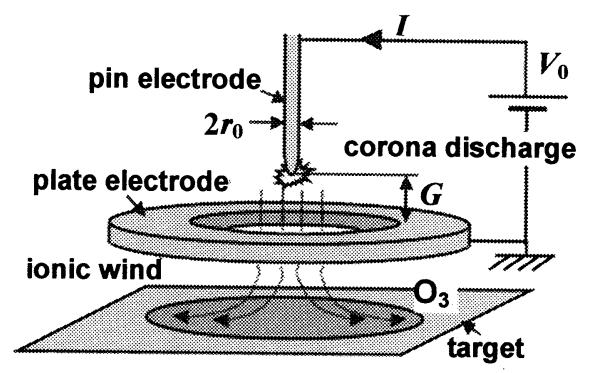

Fig. 1 Conceptual drawing of ozone fan utilizing pin-to-plate corona discharge system.

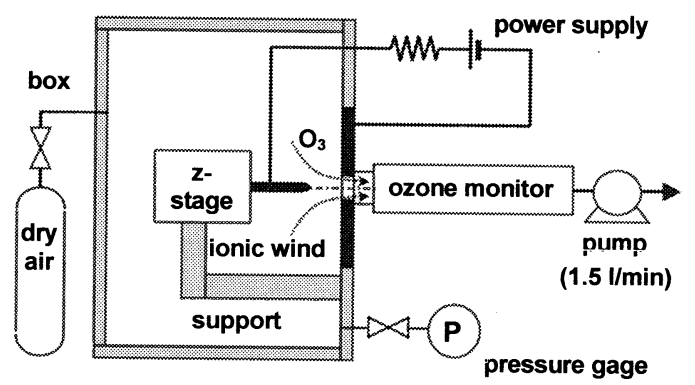

Fig. 2 Experimental setup to measure ozone generation in pin-to-plate gas discharge system.

$2 \cdot 2$ オゾンの測定方法 放電時のオゾン発生量 を測定するために，図 2 に示すような装置を製作した． すなわち, 密閉容器内に放電部を収納し, 発生したオ ゾンをナイロン製のチューブを介して紫外線吸収式 オゾンモニタ(荏原実業社製 EG-2001D)に導入した. オゾンモニタにはポンプが内蔵されており, 1.5 liter/min の流量で排気される構造になっている. オゾ ン生成は湿度の影響を受けるので, 圧力計で監視しな がら,オゾンモニタの排気流量にバランスする量の乾 燥空気を密閉容器に注入した。 密閉容器は, 放電部を 乾燥空気で満たすため, および発生したオゾンがオゾ ンモニタ外へ漏洩することを防ぐためのものである. 針電極と平板電極間のギャップは, サポートを介して 針電極に接続した z-stage で調整できる構造になって いる.

定常状態におけるオゾン濃度を測定するために，オ ゾン濃度の測定に際しては, 正コロナの場合は 10 秒 間の測定值の平均とし, 負コロナの場合にはストリー マ放電によるゆらぎを平均化するため, 60 秒平均の 值を用いた。

電極間に印加する直流電圧は, 松定プレシジョン社 製高圧電源 HEOPS-1B30 (出力電圧-10～10 kV) を使 用し, 回路に直列に挿入したシャント抵抗の電圧ドロ
ップからオシロスコープ(Tektronix 社製 TDS3014B) により電流を測定した.

\section{3. オゾンの生成解析}

針対平板電極系放電場におけるオゾン生成に関し てはすでに報告済であり ${ }^{(5)}$, 本研究でもこれとほぼ同 じ方法を用いて計算した. 解析方法の概要は以下のと おりである。

図 3 (a) に示すような実際の針対平板電極系は 2 次 元系であり,そのままでは解析的な取り扱いが困難な ので，まずこれを図 3 (b) に示すような 1 次元の同心 球対球電極系で近似する. 図 3 (b) に示すような系に おける定常コロナ放電場での電子一分子間の反応率, すなわち, 単位時間当たりの反応数 $W$ は, 全電流 $I$ に占める電子電流の割合 $\psi(r)$ と反応率係数 $\alpha_{r}$ を用い て, 次式で与えられる.

$$
W_{ \pm}=\frac{1}{e} \int_{r_{0}}^{R} \psi_{ \pm}(r) \alpha_{r}(r) d r
$$

ただし, $e$ は電子の電荷量, $r$ は半径位置, $r_{0}$ と $R$ は 中心の球電極 (放電電極) と外周の中空球電極 (集電電 極)の半径である．添字士は十が正コロナ，一が負コ ロナであることを示す.

$\alpha_{r}(r)$ は, $A\left(=5.6 \times 10^{-20} \mathrm{~m}^{2}\right), B\left(=2.1 \times 10^{-19} \mathrm{Vm}^{2}\right)$ を 実験係数, $E(r)$ を電界とすれば，電子の衝突電離係 数 $\alpha$ と類似の次式で関数近似できる.

$$
\alpha_{r}(r)=A n_{m} \exp \left(-\frac{B n_{m}}{E(r)}\right)
$$

負コロナの場合の $\varphi_{-}(r)$ は, タウンゼントの理論で 定義される電子の衝突電離係数 $\alpha$ と $^{(7)}$, 陰極に衝突す る陽イオン 1 個当たりに放出される平均 2 次電子数 $\gamma$ $[\ln (1 / \gamma)=8]$ を用いて, 次式で与えられる.

$$
\psi_{-}(r)=\gamma \exp \left(\int_{r_{0}}^{r} \alpha_{-}(r) d r\right)
$$

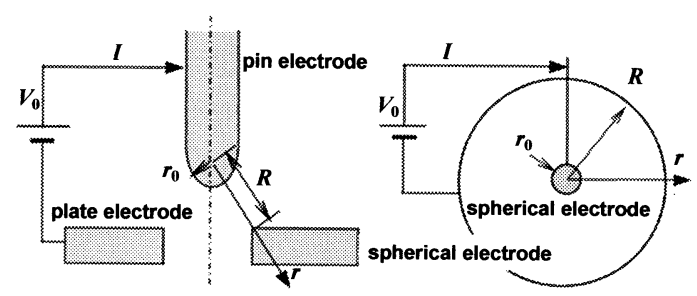

(a) pin-to-plate system

(b) concentric sphere system

Fig. 3 Pin-to-plate system and modified concentric sphere electrode system. 
電子の衝突電離係数 $\alpha_{-}(r)$ は, 電離によるもの(次式 第 1 項) と電子の付着によるもの (次式第 2 項) の差で 表すことができる.

$$
\alpha_{-}(r)=C n_{m} \exp \left(-\frac{D n_{m}}{E(r)}\right)-F n_{m}
$$

ただし, $C\left(=3 \times 10^{-20} \mathrm{~m}^{2}\right), D\left(=8 \times 10^{-19} \mathrm{Vm}^{2}\right), F(=$ $\left.2 \times 10^{-23} \mathrm{~m}^{2}\right)$ は実験係数である.

いっぽう, 正コロナの場合には

$$
\psi_{+}(r)=\exp \left(\int_{r_{0}}^{r}-\alpha_{+}(r) d r\right) .
$$

であり，電子の付着による減少はないので， $\alpha_{+}(r)$ は 下式となる.

$$
\alpha_{+}(r)=C n_{m} \exp \left(-\frac{D n_{m}}{E(r)}\right)
$$

放電場における電界は, 放電によって発生する電荷 によって緩和されるので, これを考慮した電界分布を 求めなければならない，放電場を単極性・定常で拡散 と対流が無視できると近似すれば, 電位 $\phi$ と電荷密度 $\rho$ に関して, 電荷保存則 $\nabla \cdot(-\omega \rho \nabla \phi)=0$ とポアソン方 程式 $\nabla^{2} \phi=-\rho / \varepsilon_{0}$ が成り立つ. ただし, $\omega$ は空気のイ オン移動度, $\varepsilon_{0}$ は真空の誘電率である. これらを境界 条件 $E=E_{0}\left(r=r_{0}\right)$ のもとに球座標系で解けば, 電界 分布は次式となる.

$$
E(r)=E_{0}\left(\frac{r_{0}}{r}\right)^{2} \sqrt{1+\frac{I}{6 \pi \varepsilon_{0} \omega r_{0} E_{0}^{2}}\left\{\left(\frac{r}{r_{0}}\right)^{3}-1\right\}}
$$

式 (7) は, 放電のない静電界分布 $E_{0}\left(r_{0} / r\right)^{2}$ が, 放電 によって緩和されることを示している. 放電電極表面

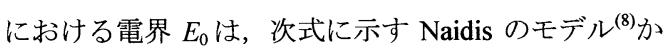
ら陰に求めた。

$$
\int_{r_{0}}^{R} C n_{m} \exp \left(-\frac{D n_{m}}{E_{0} r_{0}^{2}} r^{2}\right) d r=\ln \left(\frac{1}{\gamma_{p h}}\right)
$$

ただし， $\gamma_{p h}$ は光電効果による平均の 2 次電子数であ る $\left[\ln \left(1 / \gamma_{p h}\right)=8\right]$.

以上の関係式より, 式 (1) は容易に数值積分でき る. 実際に観測されるオゾン濃度 $c[\mathrm{ppm}]$ は, 空気流 量を $Q[l / \mathrm{min}]$ とすれば, $c=2.233 \times 10^{-15} W_{ \pm} / Q$ であ る.

\section{4. 結果と考察}

$4 \cdot 1$ ギャップの影響＼cjkstart電極間ギャップをパラメ 一タとした場合のコロナ電流一オゾン濃度特性を図

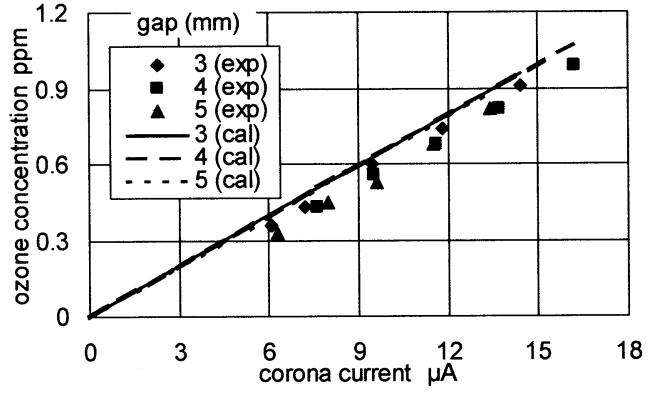

Fig. 4 Ozone generation with respect to positive corona current. -effect of gap- $\left(2 r_{0}=0.5 \mathrm{~mm}\right)$

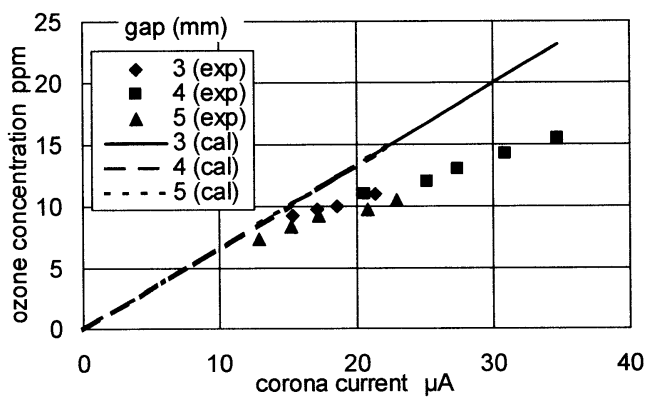

Fig. 5 Ozone generation with respect to negative corona current. -effect of gap- $\left(2 r_{0}=0.5 \mathrm{~mm}\right)$

4 (正コロナの場合) と図 5 (負コロナの場合)に示す. 図より，まず実験值と計算值がおおむね一致し，正負 コロナに関わらず, コロナ電流に対してほぼ線形の関 係が得られていることがわかる.この特徴を利用する と,コロナ電流によって生成オゾン量をコントロール できるので，実用上好都合である。いっぽう，正負コ ロナともにオゾン生成量はギャップにほとんどよら ない.これは正負いずれの場合にもオゾンは針電極の ごく近傍で生成するためである(5). 1 次元近似にもか かわらず計算值と実測值が比較的よく一致するのは, オゾン生成が針電極のごく近傍で生じ, 平板電極側の 影響をほとんど受けないためであると考えられる.

また, 実験・計算とも約 11 倍程度負コロナが正コロ ナより高いオゾン濃度となった.これは, 既報に報告 したように ${ }^{(5)}$, 放電電極近傍での電子密度分布の違い によるものである. 後述のように, この特徴を利用す ることによって, 排出空気中のオゾンの有無を容易に 切り替えることができる.

4-2 針径の影響針径をパラメータとした場合 のコロナ電流一オゾン濃度特性を図 6(正コロナ) と 図7(負コロナ)に示す. 図より, 正負コロナとも, 針 径が大きいほど電流あたりのオゾン濃度が高くなる 


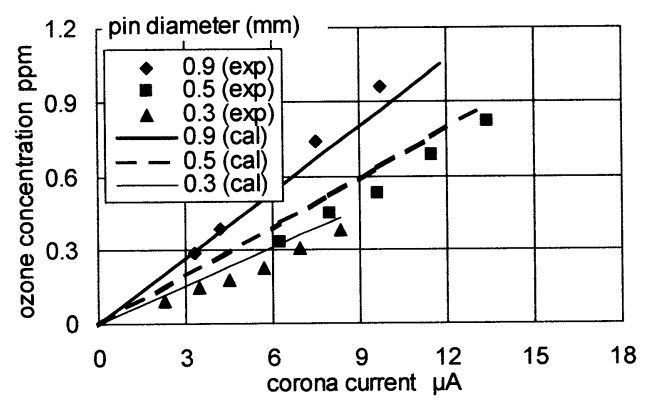

Fig. 6 Ozone generation with respect to positive corona current. -effect of pin diameter- $(G=5 \mathrm{~mm})$

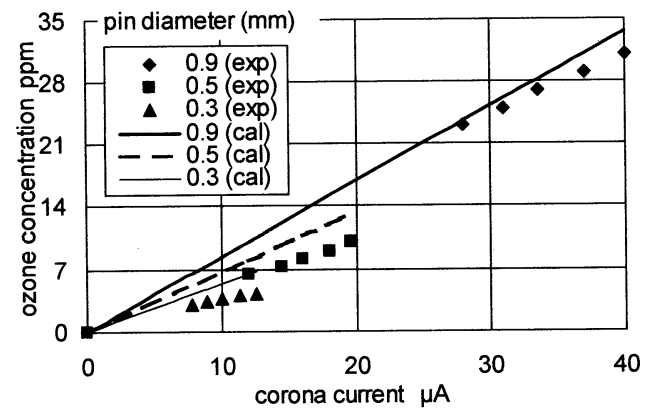

Fig. 7 Ozone generation with respect to negative corona current. -effect of pin diameter- $(G=5 \mathrm{~mm})$

ことがわかる. 針電極径が大きいほど針電極先端付近 における放電範囲が広くなるためである ${ }^{(5)}$.

4 -3 エネルギ一効率上記の結果を整理して,オ ゾン生成のエネルギー効率を算出した. ただし, 入力 は放電系の消費電力 $\left(V_{0} I\right)$ であり，オゾン生成エネル ギーを $2.5\left(\mathrm{kWh} / \mathrm{kgO}_{3}\right)$ とした.

ギャップをパラメータとした場合のコロナ電流一 効率特性を図 8 (正コロナ) と図 9(負コロナ)に示す. 図より, 正負コロナともにコロナ電流が増加するとわ ずかながらエネルギー効率が減少することがわかる， これは, オゾン生成量はコロナ電流に比例するが, コ ロナ電流は印加電圧の 2 乗に比例することによる.ま た, 正負コロナともギャップが小さいほど, 効率が高 いことがわかる.これは, 電流あたりのオゾン生成量 はギャップに依存しないが, ギャップが小さいほど低 い印加電圧でも大きなコロナ電流が流れるためであ る.

つぎに, 針径をパラメータとした場合のコロナ電流 一効率特性図 10 (正コロナ) と図 11 (負コロナ)に示す. 図より, 針径が大きいほど効率が高くなっていること がわかる. 正コロナと負コロナでは, 負コロナのほう が効率が 14 倍ほど高くなり, ギャップ $G=5 \mathrm{~mm}$, 針
径 $2 r_{0}=0.9 \mathrm{~mm}$ において, 効率 $6.3 \%$ となった. この 值は工業用のオゾナイザーに比べて極端に低いもの であるが，入力電力の絶対值は，たかだか $0.2 \mathrm{~W}$ (印 加電圧 $-5 \mathrm{kV}$, コロナ電流 $40 \mu \mathrm{A})$ 程度に過ぎないため, 実用上はほとんど問題にならないと考えられる.なお, ファンの効率もたかだか $1 \%$ 以下であるから ${ }^{(6)}$ ，コロ ナ放電場におけるエネルギーのほとんどはジュール 損として消費されていることになる.

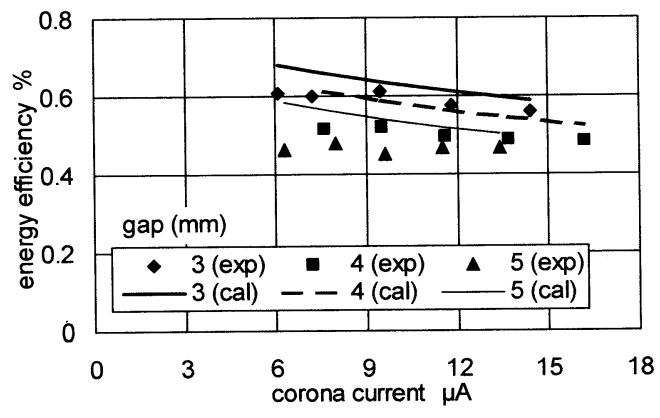

Fig. 8 Energy efficiency of ozone generation with respect to positive corona current. -effect of gap$\left(2 r_{0}=0.5 \mathrm{~mm}\right)$

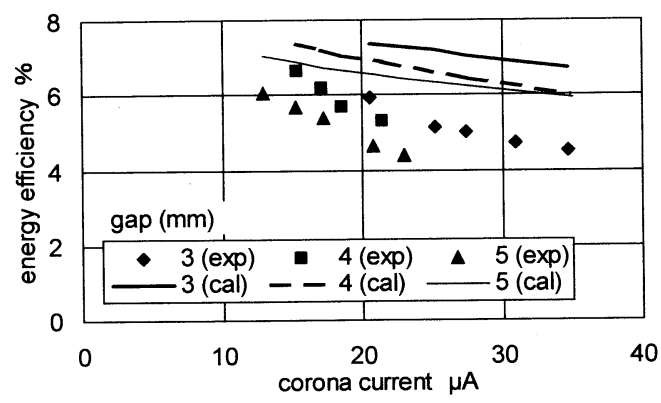

Fig. 9 Energy efficiency of ozone generation with respect to negative corona current. -effect of gap$\left(2 r_{0}=0.5 \mathrm{~mm}\right)$

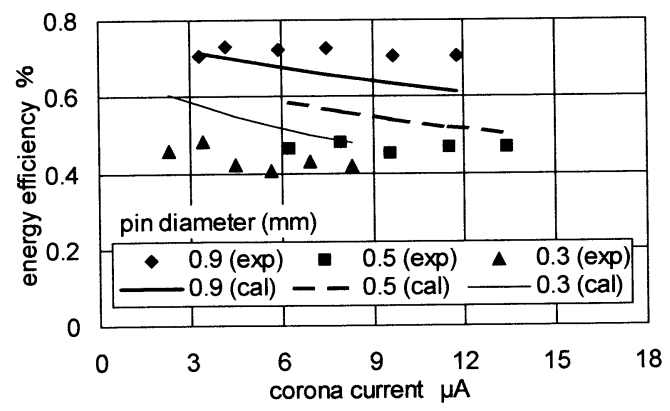

Fig. 10 Energy efficiency of ozone generation with respect to positive corona current. -effect of pin diameter$(G=5 \mathrm{~mm})$ 


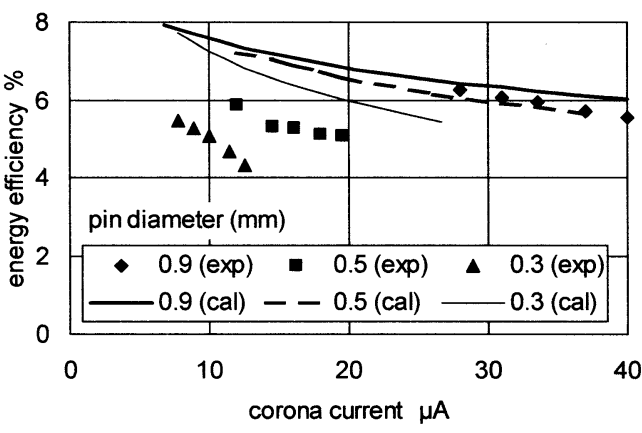

Fig. 11 Energy efficiency of ozone generation with respect to negative corona current. -effect of pin diameter $(G=5 \mathrm{~mm})$

$4 \cdot 4$ 温度の影響 キセノンライト(三永電気製作 所 XEF-501S) を照射して針電極を加熱したときの針電 極温度とオゾン濃度の関係を図 12 (正コロナ) と図 13 (負コロナ)に示す. 4.1, 4.2 節に示したようにオゾン 濃度と電流は比例するので, 単位電流あたりのオゾン 濃度で評価した．針電極温度測定には熱伝対型温度計 (安立計器社製センサ: ST-24E-010, 本体: HA-100E) を用 いた。 センサが放電場に影響を及ぼすことを防ぐため

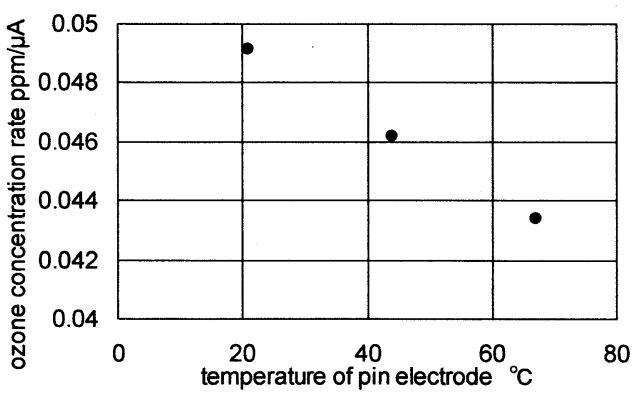

Fig. 12 Temperature dependence of ozone generation per unit positive corona current. $\left(G=5 \mathrm{~mm}, 2 r_{0}=0.5 \mathrm{~mm}\right)$

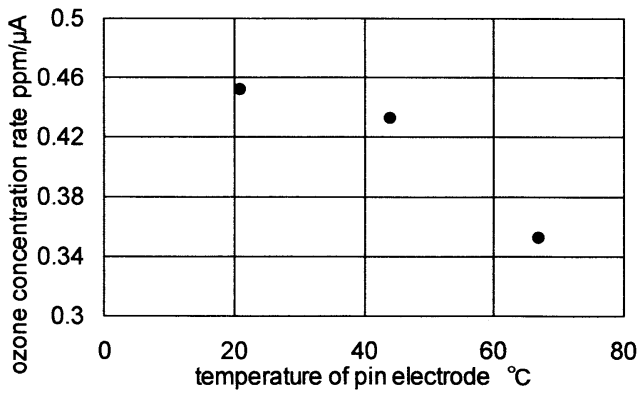

Fig. 13 Temperature dependence of ozone generation per unit negative corona current.

$\left(G=5 \mathrm{~mm}, 2 r_{0}=0.5 \mathrm{~mm}\right)$
に, 電圧印加を切断した直後に温度測定し, この值か ら放電時の温度を推定した. 測定結果より, 針電極温 度が高いほどコロナ電流あたりのオゾン濃度が小さ くなることがわかる。これらの結果は $\operatorname{Markin}^{(9)} や$ Ohkubo $^{(10)}$ らの研究と定性的な傾向は一致しており, 妥当な結果であるといえる.

4.5 オゾンファンの特性＼cjkstart針対平板電極系コロ ナ放電場を利用したイオン風の送風性能は既報に報 告したとおりであり ${ }^{(6)}$, その風量一静圧特性と本研究 で得られたオゾン生成特性を組み合わせれば, 本機構 のオゾン送風機構としての性能が評価できる．図 14(正コロナ), 図 15(負コロナ)にこれらをまとめた 結果を示す．風量一静圧特性は JIS 規格 (JIS B 8330) に準じて，風量を熱式質量流量測定装置(堀場エステ ック社製 SEF-7330R-2LM) を, 静圧をデジタル微差圧 計 (長野計器製 GC62)を用いて測定したものである. 図 14, 15 は, 既報 (6) に報告した風量一静圧特性に, 本研究で測定した流量 1.5 liter/min でのオゾン濃度を, 図示の風量での值に換算して示したものである. 図か

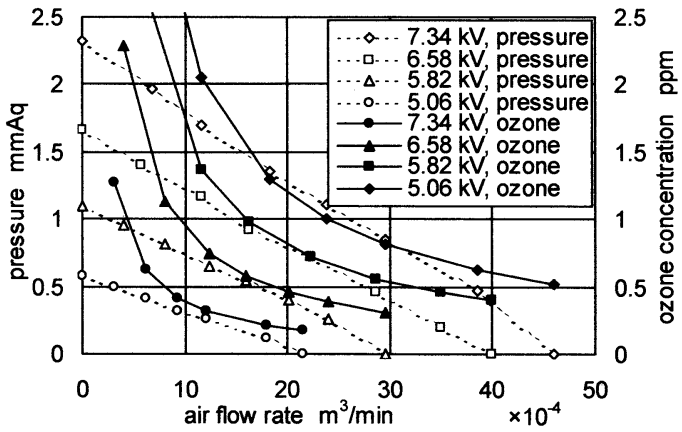

Fig. 14 Performance of ozone fan. ( $G=5 \mathrm{~mm}, 2 r_{0}=0.5$ $\mathrm{mm}$, positive corona)

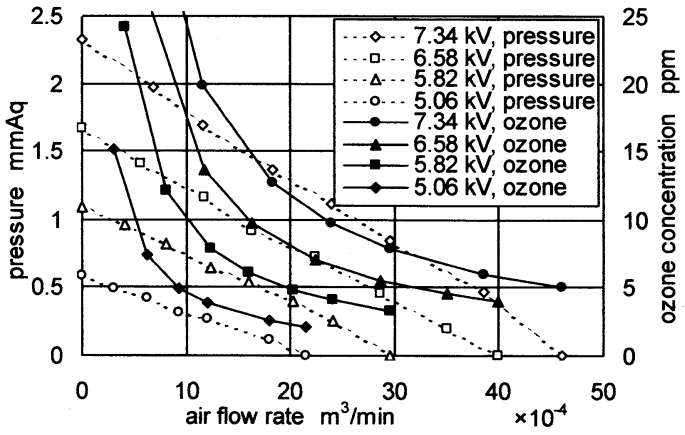

Fig. 15 Performance of ozone fan. ( $G=5 \mathrm{~mm}, 2 r_{0}=0.5$ $\mathrm{mm}$, negative corona) 
ら負コロナでは $10 \mathrm{ppm}$ オーダーのオゾンが送風できる ことがわかる.これに対して, 正コロナでは $1 \mathrm{ppm}$ 程 度であるが, 微小流量での值であり, 排気・拡散などに よって, 容易に労働環境におけるオゾンガス濃度の許 容值である $0.1 \mathrm{ppm}$ 以下にできる. 印加電圧によって正 負コロナを切り替えることは容易であり, 同じ機構で オゾンが必要な場合とオゾンが不必要もしくはオゾン の存在が不都合な場合を瞬時に変えることができる.

\section{5. 結言}

針対平板電極系放電場を利用したオゾン送風機構 を開発した. 気体放電理論にもとづく解析の結果は実 測值によく一致し, 実験結果とあわせて, 以下の知見 が得られた。

（1）生成オゾン量は，正負コロナに関わらず，コロナ 電流にほぼ比例する。

(2) 正負コロナとも, 針径が大きいほど電流あたりの 生成オゾン量は大きくなるが, ギャップにはほとんど よらない.

(3) 負コロナは正コロナより約 11 倍程度オゾンを多 く生成する.したがって, 局所酸化等でオゾンを効果 的に利用する時には負コロナ放電を,オゾンの影響を 小さくして送風効果だけを利用する時は正コロナ放 電とする, などの使い分けが可能である.

(4) オゾン生成のエネルギー効率は, 負コロナでも 数\%程度であるが, 入力電力の絶対值は, $1 \mathrm{~W}$ 以下で あるため, 実用上はほとんど問題にならないと考えら れる。

(5) 針電極温度が高いほど生成オゾン量は少なくな る.

友寄高治君 (早稲田大学)には実験を手伝っていた だいた.また本研究は, 科学研究費 (基盤研究 $\mathrm{B}$ )によ るものである. 深く感謝いたします.

\section{文献}

(1) K. Yamamoto, K. Shitara and K. Hirose, Development of High Concentration Ozone Generator, Ishikawajima Harima Giho, 36, 3 (1996) pp.153-158.

(2) M. Takebe, K. Nakamura, N. C. Paul, K. Iiyama, and S. Takamiya, GaAs-MISFETs With Insulating Gate Films Formed by Direct Oxidation and by Oxinitridation of Recessed GaAs Surfaces," IEEE Trans. Electron Devices, 51, 3 (2004) pp.311-316.

(3) Z. B. Guzel-Seydim, A. K. Greene and A. C. Seydim, Use of ozone in the food industry, Lebensm.-Wiss. u.-Technol, 37 (2004) pp.453-460.

(4) L. Gaunt, S. Higgins and J. Hughes, Decontamination of surface borne bacteria by ionized antimicrobial vapours, J. Electrostat, 63 (2005) pp.809-814.

(5) H. Kawamoto, Ozone Generation in Corona Discharge at Pin Electrode of Electrophotography Charger, J. Imaging Sci. Technol, 44, 5 (2000) pp.452-456.

(6) S. Umezu, T. Torikai and H. Kawamoto, Micro Fan Utilizing Ionic Wind Induced in Pin-to-Plate Discharge System, Trans. Japan Society of Mechanical Engineers, Series C, 73, 727 (2007) pp.789-795.

(7) J. W. Gallagher, E. C. Beaty, J. Dutton and L. C. Pitchford, An Annotated Compilation and Appraisal of Electron Swam Data in Electronegative Gases, $J$. Phys. Chem. Ref. Data, 12, 1 (1983) pp.109-152.

(8) G. V. Naidis, Modeling of plasma chemical processes in stable corona discharges at thin wires, J. Phys. D: Appl. Phys, 25 (1992) pp.477-441.

(9) B. Makin, I. I. Inculet, Generation of Ozone form Heated Positive Corona Wires for Electrostatic Charging, IEEE IAS (1973) pp381-385

(10) T. Ohkubo, S. Hamasaki, Y. Nomoto, J-S. Chan and T. Adachi, The Effect of Corona Wire Heating on the Downstream Ozone Concentration Profiles in an Air-Cleaning Wire-Duct Electrostatic Precipitator, IEEE Trans. Industry Appl, 26, 3 (1990) pp.542-549. 